\title{
CrimRxiv
}

\section{Is There a Relationship Between Prison Conditions and Recidivism?}

Esther F.J.C. van Ginneken, Hanneke Palmen

Published on: Mar 04, 2022

DOI: 10.21428/cb6ab371.e034df28

License: Creative Commons Attribution 4.0 International License (CC-BY 4.0). 
